Article

\title{
The New European Political Arithmetic of Inequalities in Education: A History of the Present
}

\author{
Romuald Normand \\ Faculty of Social Sciences, University of Strasbourg, France; E-Mail: rnormand@unistra.fr
}

Submitted: 2 April 2021 | Accepted: 24 June 2021 | Published: 16 September 2021

\begin{abstract}
The article describes the emergence and development of positive epistemology and quantification tools in the dynamics of inequalities in education. It contributes to a history of the present at a time when datafication and experimentalism are reappearing in educational policies to justify the reduction of inequalities across international surveys and randomised controlled trials. This socio-history of metrics also sheds light on transformations about relationships historically established between the welfare state and education that have shaped the representation of inequalities and social programs in education. The use of large-scale surveys and controlled experiments in social and educational policies developed in the 1920s and 30s, even if their methods and techniques have become more sophisticated due to statistical progress. However, statistical reasoning is today no less persuasive in justifying the measurement of student skills and various forms of state intervention for "at-risk" children and youth. With the rise of international organisations, notably the European Commission, demographic issues related to school population and the reduction of inequalities have shifted. It is less a question of selecting the most talented or gifted among working-class students than of investing in human capital from early childhood to improve the education systems' performance and competitiveness for the lifelong learning economy and European social investment strategy. This article attempts to illustrate this new arithmetic of inequalities in education at the European level.
\end{abstract}

\section{Keywords}

education; epistemology; inequalities; metrics; policy; welfare

\section{Issue}

This article is part of the issue "Education, Politics, Inequalities: Current Dynamics and Perspectives" edited by Kenneth Horvath (University of Lucerne, Switzerland) and Regula Julia Leemann (University of Teacher Education FHNW, Switzerland / University of Basel, Switzerland).

(C) 2021 by the author; licensee Cogitatio (Lisbon, Portugal). This article is licensed under a Creative Commons Attribution 4.0 International License (CC BY).

\section{Introduction}

Through several chronological tables, Desrosières (1998, 2002) and Thévenot (2016) showed how statistical thought defines a way of thinking simultaneously the society, modalities of action within it, and its modes of description. Statistics are conceptualised, legitimised and institutionalised through time between sciences and the State. The statistical argument permanently combines a "tool of proof," strongly characterised by mathematical formalism and a "tool of coordination," implemented particularly by administrative registers and various survey methods.

Inspired by Desrosières and Thévenot, our article is based on research carried out by historians in social sciences and statistics, and discourse analysis based on materials produced by international organisations (reports, recommendations, technical, and statistical documents) that show how metrics have guided social policies in governing population with major consequences in knowing and measuring inequalities (Dolowitz et al., 2020; Foucault, 2002; Miller \& Rose, 2008). Indeed, to acquire accurate knowledge and reliable measurements in social and educational policies, the State historically gave these sciences opportunities to master a calculative space and to produce cognitive and technical representations of inequalities.

Our research is situated in an international but heterogeneous space of sociological studies on quantification and the role of numbers in developing society and 
the economy. Researchers inspired by the history and philosophy of sciences have studied the influence of statistics and probabilities on state administration and public policies (Gigerenzer et al., 1990; Hacking, 1990; Porter, 1995). Others have criticised the performativity of metrics (ranking, ratings, indicators, benchmarks) in the economy, organisations, and societies ( $O^{\prime}$ Neil, 2016; Power, 1997). For example, Porter (1995) demonstrates how the authority produced by quantification and standardised calculations have influenced decisionmaking, while quantitative expertise has been developed in search of "mechanical objectivity." This authority and mechanical objectivity have combined and extended historically into policy areas controlled by the State and its bureaucratic administration. The authority of numbers is not only technical or methodological: It is also moral and social because the use of numbers responds to demands for justice, accountability, or impartiality. In the same vein, Espeland and Stevens (2008) explain, borrowing from Austin's theory of language, that quantification and numbers, like words, are part of grammar and conventions, which forge representations while possessing a perlocutionary dimension, even if their meaning may vary in time and space.

Like Lampland (2010), our article emphasises quantification techniques and their formal representation that are instrumentalised in the design of standards, but we do not study practices or the effects of quantification in making the self, behavioural changes, and individual experiences, including self-tracking and algorithms generated by digitalisation (Lupton, 2016; Neff \& Nafus, 2016; Popkewitz, 2018). Even if we have previously studied the lifelong learning self and agency in the making of European statistics (Normand \& Pacheco, 2014), our research is close to those examining comparisons and commensurations induced by the international extension of statistics into rankings and accountability tools and systems (Espeland \& Sauder, 2016; Hutt, 2016, 2017). We have previously identified some modes of classification, categorisation and standardisation related to the fabrication of measurement in education and its informational structure embedded in European statistics (Normand, 2020). In doing this, we have followed French studies on quantification which, after Desrosières and Thévenot, based on the theory of conventions, have shown some links between social categorisations, quantification and conventions as well as the political economy of coding, or investments in a form that participate in the politics of numbers (Desrosières, 2011; Diaz-Bone \& Didier, 2016; Thévenot, 1984, 2011, 2019). These perspectives, both pragmatic and historical, allow us to work on the socio-political and epistemic constellations that transform governmentality and the welfare state. We also characterise, in the following French studies, the role of quantification in the economisation of education, particularly neo-liberal reforms guided by human capital theory that frames educational activities and organisations from a market perspective (Callon,
2010; Callon \& Muniesa, 2005; Chiapello \& Walter, 2016; Muniesa, 2014).

Inspired by the sociology of quantification initiated by Desrosières and Thévenot, in choosing specific epistemic periods the first part of this article shows how political calculation networks and technologies have served to build population governance and welfare with some consequences for conventions related to inequalities in education (Bulmer, 1978; Normand, 2013, 2020): These tools, such as IQ tests, have been institutionalised to control and measure the intelligence of the population; statistical studies have been greatly used to justify and support social and educational policies; social experiments have been developed to target social interventions.

The second part of the article illustrates a certain continuity in these relationships between the welfare state, sciences, and population governance at the European level. However, knowledge and metrics developed by new governing sciences, even if they still aim to improve the "quality of the population," shape a metrology that can be named "new political arithmetic." Indeed, the latter strongly modifies technical, cognitive, and political representations as conventions in measuring inequalities. While PISA is a new measuring instrument of inequalities in education, based on differences in student achievement from psychometric tests, the international survey has also been part of continuous transformations related to equal opportunities, their metrics and conventions since the 1920s.

The article not only continues the history of statistical reasoning applied to education by showing some continuities and discontinuities related to established links between statistics, metrology, and the State, at a time the European Commission (EC) is more influential. From a history of the present, it also studies the demographic and population governmentality associated with reshaping metrics, as was the case in the 1920s and 30s, through new relationships and conventions set up between the welfare state, education, and large-scale surveys. It also demonstrates that this new governmentality in education, through statistical rationalisation and design, include policy concerns on the welfare states in Europe that necessarily impact education and its quantification.

\section{Tests, Large-Scale Surveys, and Controlled Experiments: The Invention of Governing Sciences for the Welfare and Educative State}

The history of the present aims to resist the presentism that characterises the study of politics and governments. Indeed, current socio-political arrangements and cultural meanings sometimes accommodate less perceptible transformations that could be highlighted by a genealogical approach. Here, we are interested in political, but also methodological and epistemological investments that have enhanced governing technologies and types of rationality that are still in use today. As Michel 
Foucault did for his archaeology of knowledge, it is possible to distinguish different periods when epistemological and political conditions are met for new statements that transform social representations and systems of thought. Popkewitz (2013) takes up these ideas in education by showing how a certain social epistemology shaping knowledge and science in education is situated in specific historical and social formations. These systems of reason build discourses and categories used to understand educational issues but also to direct modes of existence among educators and children. Following these theoretical assumptions, we propose here to characterise some important historical moments in the invention of governing sciences that characterise stable and durable links between the welfare state, education, and metrics of inequalities, even if these relations are then called upon to be transformed. We are particularly interested in the state's unceasing quest for the "quality" of the population for which, according to some theories, education plays an important role, while it needs to select and guide people through education systems (which refers to measuring the capacities of the educated), and in mastering scale games for governmentality (through indicators and experimental methods).

Our first epistemic period (the quest for largescale surveys) is related to the 1920s and 30s, when a part of US social sciences relied on statistics and methods inspired by natural sciences (Bulmer, 1984). Experimental and social research had established links with medicine and psychology, while the latter had become credible expertise for social reforms. These scientific standards were also widely implemented in the field of education. Gradually, positivist sciences based on statistical methods paved the way in the 1950s to social planning and large-scale surveys focusing on poverty and inequalities that are still in use today.

At the same time, in the UK, during the second epistemic period (the welfare state, eugenics, and statistics), eugenicist thinking was concerned about improving the population quality and selecting gifted and talented people for economic development. The alliance between sociologists, social reformers, charities, and eugenicists seemed self-evident (Bulmer, 1985). However, metrics in social sciences were scattered in local survey projects and large-scale surveys were only developed after WWII under the umbrella of a governmental service while they changed the representation of inequalities in education (Kent, 1985; Whitehead, 1985). The idea of "human stock" forged by eugenicists and social biologists has been later reformulated into "human capital" by economists.

In the 1950s, our last epistemic period (social indicators, planning, and controlled experiments), a new science of social indicators emerged in the US, followed by social experiments which legitimised new welfarist interventions and were progressively borrowed by the OECD and its member countries. This experimentalism served to advocate evidence-based methods disseminated in US welfare and education and later extended to an inter- national audience through policy borrowing and lending (Normand, 2016).

\subsection{The Quest for Large-Scale Surveys and the Institutionalisation of Governing Sciences}

During the 1920s, US psychology abandoned an individualistic perspective in data collection to build more totalising statistical tools and approaches (Danziger, 1994, pp. 68-87). Administrators wanted school systems to rationally and efficiently allocate individuals according to their mental abilities. This implied new selective practices (standardisation of curricula, classifications by age, student testing) but also the choice of statistical populations according to standards inspired by the Galtonian orthodoxy (Tyack, 1974; Tyack \& Hansot, 1982). As a result, mental testing played a central role in US psychology while, in the meantime, school administrators legitimised this academic discipline to lead reforms on behalf of efficiency despite racial and eugenicist segregation and selection (Callahan, 1962).

However, mental tests made it possible to work on individual differences and statistical series while classifying individuals according to eugenicist assumptions (Danziger, 1994, pp. 113-117). Studies on treatment groups were then published in specialist journals and such devices were adopted in psychology (Dehue, 2001). McCall (1923) enshrined the method in his textbook How to Experiment in Education? He justified this type of experiment with the possibility of saving money for the wasteful school administration. The book set out complex schemes of controlled experiments and randomisation for school districts.

At that time, part of the US sociology shared scientific and positivist views with psychology and justified empiricism based on systematic observations and "unbiased" and "ethically neutral" procedures (Bannister, 1987). With Franklin H. Giddings and his fellows at Columbia University, statistical studies were developed in this direction (Camic \& Yue, 1994). Franklin Stuart Chapin, like Giddings, was attracted by Karl Pearson's thoughts in his book The Grammar of Science (1892). In The Elements of Scientific Method in Sociology (1914), he argued that statistical methods could establish universal laws for society and should be at the top of the hierarchy among methods used in social sciences (Bannister, 1987, pp. 144-160). During these years, Chapin's Department of Sociology was the locus in advocating these new conceptions under the umbrella of the American Sociological Association, but also the influence of George Lundberg and Harold A. Phelps (Platt, 1996, pp. 212-223). These sociologists were greatly inspired by the spread of the Vienna Circle's ideas, while John B. Watson's behaviourism and Percy W. Bridgman's operationalism strengthened the vision that social sciences could be brought closer to natural sciences.

Beyond these major epistemological and methodological premises, the type of research advocated by 
Giddings and his fellows required a new scientific organisation. The latter was supported by major US foundations, notably the Rockefeller Foundation (Platt, 1996, pp. 142-150; Turner \& Turner, 1990, pp. 41-45). The foundation helped to develop large-scale statistical surveys with the creation of the Institute for Social and Religious Research. Research funding was supplemented by other foundations (e.g., Laura Spelman Rockefeller Memorial Fund, Carnegie Corporation). For these institutions, social research was called to improve the social and physical well-being of populations but also to rationalise social activities through efficient management.

In 1923, the American Political Science Association and the American Sociological Society joined together to create a special council, the Social Science Research Council (SSRC) to better coordinate research efforts and to develop so-called scientific methods. Charles Merriam, the head of the Department of Political Science at the University of Chicago, managed the SSRC's activities with the Laura Spelman Foundation. During the Great Depression, many SSRC members participated in William F. Ogburn's report on recent social trends. Influenced by statisticians such as Pearson, the sociologist proposed a "comprehensive and unbiased examination of facts" through major surveys on the US society (Bannister, 1987, pp. 179-187). President Hoover, who had committed the US to broad social reforms, hoped that these surveys would provide a scientific and prospective vision for his federal welfare policy (Bulmer, 1983).

This brief account of the history of US social sciences sheds light on how the welfare state metrics were developed at the crossroads of large-scale surveys and social experimentation. By moving away from social work, and by claiming to become an objective science like psychology, sociology also asserted itself as a governing science, capable of guiding social policies. This trend was confirmed in the 1960s with the launch of anti-poverty programs, which were supported by large-scale surveys on inequalities in education, particularly the one launched by Tyler (1966) for the JohnsonKennedy administration (the forerunner of the National Assessment of Educational Progress) and another by Coleman et al. (1966), which had a great impact on compensatory education policies in the US.

\subsection{The Welfare State, Eugenics, and Statistics: The UK Political Arithmetic During the Inter-War Period}

In the UK, during the 1920s, eugenics was inspired by Francis Galton and used knowledge on heredity and social biology as well as statistics to develop psychology and to measure intelligence (Sutherland \& Sharp, 1984, pp. 25-56; Wooldridge, 1994). Karl Pearson was one of the main representatives of this research field. His Galton Eugenics Laboratory (1907-1933) was the most famous biometric research centre in the country. It revolutionised the application of statistical tech- niques by compiling voluminous data on populations. Orthodox eugenicists such as Pearson advocated the principles of natural selection and the strict application of biological laws, but natalists were more in favour of extending social legislation to protect children and to develop new institutions (guidance clinics, nursery schools, day-care centres). This new social philosophy wanted to provide adequate pensions, marriage bonuses, family allowances or tax reductions for the most talented individuals.

William Beveridge, the father of British welfare and then Director of the London School of Economics, after leading eugenicist surveys on fertility, promoted the idea of family allowances and wage supplements to raise birth rates. Orthodox eugenics, concerned about regulating the "human stock," gradually joined natalists and "positive" eugenics was finally promoted by researchers such as Alexander Carr-Saunders (Schneider, 2002; Soloway, 1990, pp. 193-202). At the London School of Economics (Scot, 2011), there was a strong interest in economics, statistics, and social biology for analysing social problems.

The Department of Social Biology was implemented in 1925 at the request of the Laura Spelman Rockefeller Memorial Fund, the one which had funded US research. Beveridge had appointed Lancelot Hogben to head the department (Wooldridge, 1994, pp. 263-270). Hogben wanted to promote a new "political arithmetic" by measuring the population quality and fighting against wasted talent while he was eager to challenge assumptions shared by eugenicist psychologists (Wooldridge, 1994). Nevertheless, Hogben supported the eugenicist vision of the planned elimination of undesirable types and characteristics within the society (Hogben, 1938). However, he encouraged Gray and Moshinsky to lead their research project that developed a radical critique against the psychometric orthodoxy and IQ testing for measuring social inequalities.

After WWII, David Glass, a disciple of Hogben, who had been appointed Professor of Demography at the London School of Economics, became the mediator between pre-war eugenics and the sociology of social mobility and large-scale surveys on social inequalities (Glass, 1954). In this intellectual climate, a group of sociologists including Floud, Halsey, and Martin undertook a study on the role of social selection in education and access to secondary schools (Halsey et al., 1956). Using the measurement of IQ and comparing their results with those of Gray and Moshinsky, they showed that middle-class scholarship students, when displaying the same intellectual abilities as middle-class children, equalised their chances of access.

Then, this nascent sociology of education began to study talents and environmental factors that impact intellectual development and academic achievement. It also raised some expectations about reducing waste and promoting a more egalitarian society (Halsey et al., 1961). It helped, along with other sciences, to promote the UK 
comprehensive school, which then spread over internationally during the 1960 s with a strong scientific and political focus on reducing inequalities in school achievement. These ideas were borrowed by the OECD. Under the dual influence of the UK and the US, OECD member countries embarked on school democratisation policies to facilitate the access of working-class students to secondary and higher education, while social classreplacing $\mathrm{IQ}$-became the variable used to analyse and compare inequalities in education.

\subsection{Social Indicators, Planning and Controlled Experiments in the US}

During the 1950s, the support of US foundations for local social studies had declined to favour large-scale surveys developed by research institutes. This new research model had strong implications (Turner \& Turner, 1990, pp. 105-121). The accumulation of statistical data gave a heuristic advantage to structuralist and functionalist theories that were promoted by researchers such as Talcott Parsons, Robert K. Merton, and Paul F. Lazarfeld. At the same time, new methodologies for investigating social inequalities were developed (Haverman, 1987). This explains the success of James Coleman's large-scale survey supported by the Kennedy-Johnson administration with the technical support of the Educational Testing Service, an agency conceptualised during WWII within the Navy to improve IQ testing (the transition from IQ to SATs for the entrance examinations in US universities; Lemann, 2000).

In the late 1950s, the Federal Department of Health, Education and Welfare published social indicators in a document titled Health, Education and Welfare Indicators and Social Trends. William Ogburn's students were involved in the development of these new statistics (Cobb \& Rixford, 1998). Under the leadership of Raymond Bauer, Albert Biderman, and Bertram Gross, social indicators were considered tools for guiding welfare policies (Bauer, 1966). This work was a followup to Ogburn's report, and it was enriched by articles published in the journal Social Indicators Research. It inspired the OECD methodology in building indicators on inequalities in education, which were judged useful for planning, until the publication of the Education at Glance series (Henry et al., 2001).

Meanwhile, federal agencies, notably the General Accounting Office (GAO) and the Congressional Budget Office (CBO) were implementing public policy evaluation programs by empowering social science researchers within the Planning, Programming, Budgeting System (PPBS). The Federal Ministry of Health, Education and Welfare was also developing the evaluation of social programs (Haverman, 1987, pp. 166-176). These were the first steps towards accountability policies that were later imposed in education as a measurement of student inequalities between students, particularly through the reuse of the NAEP (National Assessment of Educational
Progress), originally designed by Ralph Tyler and later resumed by the Educational Testing Service (Jones, 1996; Lehmann, 2004). In the late 1960s, the psychologist Donald T. Campbell had also published an article that became a reference for evaluators (Campbell, 1969). Reforms as Experiments advocated the idea of extending the "laboratory logic" to all of society (Campbell \& Stanley, 1963). Together with his colleague Stanley, Campbell set a new "standard" for the social sciences by considering the researcher as a "methodological servant of the experimental society" (Campbell, 1975).

Subsequently, these ideas of "social experiments" were strongly developed in a political climate of reducing public expenditure due to the Vietnam War's consequences, as social programs were losing their scope in favour of more targeted and less costly schemes. The first large-scale social experiment was conducted in New Jersey by the Poverty Research Institute at the University of Wisconsin-Madison after a request from the Office of Economic Opportunity, the federal agency in charge of fighting against inequalities. The 1970s was the "decade of experimentation" (Greenberg \& Robins, 1986). Millions of dollars from the federal budget were spent on social programs based on controlled experiments in welfare, policing, and justice (Young et al., 2002). They were used to evaluate some incentive effects of social reforms, particularly in studying educational behaviours among young people through various programs: New Chance, LEAP (Leadership, Education and Athletics in Partnership) in Ohio, and Learnfare in Wisconsin. In education, one of the most important experiments was the evaluation of class size reduction in Tennessee (Mosteller \& Boruch, 2002). US evidence-based research in welfare and education policies was later legitimised internationally through the OECD (references blinded for peerreview). It also served as a landmark for human capital economists to improve their methods and analytical models through experimentalism.

\section{The European Political Arithmetic and Social Investment Strategy: Between International Surveys and New Governing Sciences}

Today, in Europe, the new conceptual and methodological apparatus of the welfare state corresponds to changes in social interventions targeting populations. Ideas for improving the "quantity" and "quality" of the population, or the "human stock," have been replaced in a common vision shared by social reformers in terms of "employability," "inclusion" and "care." The vocabulary of "soft skills" or "special needs" has replaced the eugenicist lexicon (idiots, backwards, retarded, under-gifted or unfit students) used to describe students "at risk" who suffer from cognitive, affective, sexual, social, and emotional "deficits." These new categories are not only shaping representations, but they are also produced by knowledge and metrics forged by new political assemblages 
involving multiple agents and institutions (Maire, 2020; Popkewitz \& Lindblad, 2020).

By political assemblages, we mean the empowerment of different epistemic communities, expert groups and policymakers gathered at the national level and around the European Open Method of Coordination (OMC; see Normand, 2010). Actor-network theory makes it possible to study these assemblages in education by analysing alliances, circulation and translation within different spaces and calculation centres from the local to the global (Fenwick \& Edwards, 2010; Fenwick \& Landri, 2012; Latour, 2005). This sociology of measurement helps to characterise some principles and components related to this international and European calculability as political instrumentalism and technology (Gorur, 2014). Between science and government, metrics articulate tools, knowledge, and agents which bypass the State and its national sovereignty (Gorur, 2011). However, similarly to the 1920s and 30s, demographic issues such as population governance remain at stake for policymakers. According to EU reports, the ageing of the population, as well as the welcoming of new migrants and women in the workforce raise concerns about maintaining a sufficient employment rate to ensure the global competitiveness of the European economy. Early childhood education, as well as social inclusion and youth "at risk" appear to challenge national education policies and to call for a new relationship between education and the welfare state.

Consequently, the epistemological and metrological matrix of the welfare state, as it has been analysed in the first part of this article, is redefined. A new alliance between psychology and economics leads to new metrics combining tests, indicators/benchmarks, social experiments, and large-scale studies. They benefit from a growing recognition of evidence-based research methods and big data, while international and European comparative surveys increasingly guide national policymaking. Indeed, PISA survey metrics promoted by the OECD and the EC have become standards to measure investment in human capital, the inequality gap in school achievement, and the performance of education systems.

In the last section of this article, we illustrate this "new European arithmetic" which transforms conventions of inequalities in education, while promoting new population governmentality and investment in education, beyond the rhetoric on a knowledge-based economy and social cohesion.

The challenge is no longer to promote a "talent pool" or "birth control" through supportive social policies, but to prevent school drop-out risks, to ensure early investments in human capital, and to develop lifelong learning cognitive and non-cognitive skills for enhancing employability and competitiveness on the European labour market. PISA and its components have replaced mental tests in measuring student skills to reduce educational inequalities.

The statistical argument has also changed. Whereas it had been based on governing student populations during compulsory schooling, particularly by scrutinising guidance and selection methods and their effects as they are revealed by major surveys, and discussing different ways of social reproduction and meritocracy, the economisation of statistical reasoning, through new metrics, has led to a focus on human capital and its psychological features, while also contributing to the analysis of input-output relations in terms of effectiveness and performance. Thus, measuring inequalities has been converted into detecting achievement and performance gaps throughout lifelong learning according to predictive patterns that substitute a neo-liberal rationale for eugenic assumptions.

Finally, in the last section, we analyse how links between the welfare state and education are also transformed. The universalist, redistributive and planning state, regulated by social indicators, becomes both experimentalist and investor, eager to control its social costs and to rationalise its interventions towards at-risk students who are selected in limited educational programs and assessed by most recent econometric and evidencebased methods.

\subsection{Measuring Skills and Targeting Youth at Risk: A New Definition of the Welfare State Based on Human Capital Investment}

Among economists, the definition of "human stock" has evolved. Initially focused on "degeneration," "deficiency" and testing the "unfit," it gradually took a more positive turn in promoting the "talent pool" and "investment in human capital." It opened access to secondary and higher education promoted by the OECD during the 1970s. Today, the theory of human capital is based on a predictive conception of children's development based on measuring skills from an early age, which would facilitate their inclusion and employability in the labour market required by the knowledge economy.

Leading economists, such as Eric Hanushek and Ludger Woessmann, are also interested in international surveys because they consider that they measure the quality and efficiency of education systems and they predict human capital investment quite well (Hanushek \& Woessmann, 2011). With other metrics designed and relayed by psychologists, they developed research and studies on the limitation of school dropouts, early school leaving and the improvement of cognitive, social and emotional skills for "children at risk." Therefore, randomised controlled trials promoted by these "experimental economics" penetrate the social and educational field which is considered to be a vast laboratory.

These conceptions of human capital are also defended by Esping-Andersen, the theorist of the New Welfare State (Esping-Andersen et al., 2001). For him, future cohorts of very modest young people, due to low fertility, will have to support a large and quickly-growing elderly population. It is, therefore, necessary to invest in the productivity of young people as early as possible 
to ensure a sustainable welfare state in Europe over the coming decades.

The other explanation lies, according to EspingAndersen, in the rapid increase in skills that are required by the knowledge economy. Reforms in European countries need to target young people who leave school early and have higher unemployment rates. These lowskilled people are unlikely to obtain high pensions and risk poverty at the end of their lives. Cognitive (and non-cognitive) skills are therefore essential to ensure good career paths and lifelong learning, to maximise the "return on investment."

Finally, as Esping-Andersen argues, it is important to fight against child poverty by reducing the economic precariousness of mothers at the bottom of the income scale and to promote their inclusion into employment. The other mechanism is to support parents' investment in their children's cognitive development. Interventions should take the form of targeted measures for "at-risk" children identified in early childhood and at the lowering stage of compulsory schooling.

Compared to eugenics, the argument appears much more progressive. It is no longer selecting the best talents and most gifted from early childhood, but investing in the cognitive development of students facing the greatest difficulties in school achievement. However, the predictive dimension attached to risks related to the loss of human capital is part of the same rationalist calculation to reduce inequalities between students, whereas metrics developed by psychologists, endorsed by economists, make this calculation objective and comparative.

\subsection{Statistical Reasoning and the Economisation of Lifelong Learning}

At the European level, PISA data have been gradually included as indicators for the OMC while human capital economists have created a network to advise the EC on education policies. The European Expert Network on Economics of Education introduces itself as a "think tank" aiming to improve decision-making and policy-making in the European education and training area (Normand, 2010). The OMC is based on quality indicators and benchmarks that monitor education systems in compiling statistical data (Alexiadou et al., 2010).

This statistical system for lifelong learning has been designed to facilitate the recognition of learning activities outside the formal education system (self-training, on-the-job training) and to value individual investment in education and training. Demographic challenges are one main motive used to improve human capital through lifelong learning as an alternative way to compulsory schooling developed during the 20th century (Normand, 2020). The OMC metrics include, in addition to PISA data, indicators on "school dropout" rates, early school leaving, and investment in education that are particularly valued by human capital economists.
The economic reasoning behind this European statistical building was earlier formulated by Tuijnman (2003), a former economist for the World Bank and the European Investment Bank. He was also involved in the development of major international surveys. For him, skills development in education can be represented as a production function, corresponding to a mathematical expression linking inputs (physical, financial, and human capital) to outputs (measuring success in different skills, values, and attitudes). Lifelong learning is seen as an "insurance policy" to minimise "market risks" associated with uncertain costs and risks in human capital investment.

This argument shows how European statistics legitimise an economic conception of paths and careers throughout people's lives, as well as a kind of new lifelong learning agency framed by the certification of skills, which opens times for greater mobility and flexibility on the European labour market (Normand \& Pacheco, 2014). The methodology of most economists, according to McCloskey (2002), is also based on a belief in positivism. Rhetoric is the art of imposing appearances on others to gain an advantage. The rhetoric of positivists has a strong persuasive power because it takes a form that has already succeeded in persuading most people: That of the natural sciences. By using this rhetoric, economists hope to convince as many people as possible that their discourse is more valuable than those of other experts or policymakers, and to gain economic (income) and social (reputation) benefits, especially from international organisations. They also build barriers to entry into the market of economists so that individuals claiming the title of economist are obliged to use their language, which is based on mathematics and statistics. Through this language, persuasion is achieved through the production of arguments and not necessarily empirical evidence. It is developed through the coherence, fluidity, or simplicity of the discourse under the cover of statistical significance tests which condition the publication of results, even if these tests are often subject to methodological bias.

\subsection{The European Commission and Its Social Investment Strategy: Towards a New Welfarist Education?}

The EC social investment strategy aims to sensitise European countries to implement new welfare state interventions through a vision combining economic competitiveness, innovation, knowledge society and human capital (EC, 2013a, 2013b). This European strategy challenges past welfare policies and targets people and their skills to maximise their opportunities in contributing to European jobs and growth through the development of social innovation and entrepreneurship. It explains why the EC has defined priority areas at the crossroads of welfare and education: Early childhood education and care, youth cognitive skills, behavioural knowledge, and early school leaving and drop-outs.

Endorsing this new conception of welfare, some countries have been engaged in social activation 
policies since the mid-1990s, mainly in Northern Europe (Hemerijck, 2013). This approach gained momentum after the publication of Esping-Andersen's book Why We Need a New Welfare State (2002), under the Belgian presidency of the European Union, after the OMC had been launched. Since 2010, which was the European year for combating poverty and social exclusion, the EC has taken up these new welfarist concepts to formulate its Europe 2020 strategy "for smart, sustainable and inclusive growth" (EC, 2010). Then, the Social Investment Package for Growth and Cohesion (Hemerijck, 2018) was created. The SIP identifies priority policy areas and target populations for social investment. In 2015, the EC carried out a comparative review of member states' respective progress in implementing these policies (EC, 2015), and then in 2017 established the "European principles of social rights" to "build a more social and fairer Europe" (European Commission, 2018, p. 31).

The EC social investment strategy promotes a conception of the welfare state as an "investor" in policies capable of activating the "capabilities" of young people, facilitating their adaptation to new "social risks" and reducing their reliance on social assistance (Morel et al., 2012). Shaping an "autonomous," "responsible," and "competent" individual is the main objective in terms of employability and inclusion into the labour market. This new role of the welfare state as an investor in human capital is justified in terms of early intervention, the development of cognitive and non-technical skills throughout life. It is also formulated in the idea of a "return on investment" after a given period of training in terms of efficiency and productive performance. These assumptions are very close to theories shared by human capital and new welfare theorists.

The welfare state is also considered an "experimenter." According to EU documents, the development of social experiments and innovations must be supported by programs and funding mechanisms such as tax incentives that extend the welfare third sector, beyond non-profit organisations, to develop a European market open to business and social entrepreneurship (Nicholls \& Murdock, 2011). These social experiments and innovations have to be directed towards "at-risk populations," with some capacities of dissemination and scaling-up when their effectiveness is proven. Recommendations are also addressed to promote policy evaluations based on classical instruments related to social investment as well as those borrowed from evidence-based research methods. In addition, private actors are also asked to develop a range of assessment tools for their social impact and actions (ROI, scoreboards, social audits, benchmarking, cost-benefit analysis, quality of life indices, and triple bottom line). In summary, the EC is preparing member states to welcome the US social experiment and evidence-based research paradigm into the European welfare and educative state.

\section{Conclusion}

What can we learn from this article characterising some diffuse and complex policy borrowing and lending mechanisms and partially explaining why social investment metrics are currently developed at the European level? Firstly, issues of welfare and education must be considered simultaneously to analyse the production of knowledge and tools measuring social inequalities. This knowledge depends on governing sciences, which affect the modalities of the welfare state interventions and the representation of populations at stake. Metrics are used to define the quantity and quality of these populations, but this definition and measurement varies from time to time. Even if human capital investment remains a strong argument, universalist policies seem progressively abandoned in favour of more welfare-targeted and experimental programs considered less costly and more profitable for reducing inequalities. Similarly, experimentalism and positivism gain a new legitimacy in measuring social and educational interventions, particularly through indicators and benchmarks, randomised controlled trials and evidence-based research methods.

Demographic challenges are still major concerns for welfarist reformers who are eager to reproduce a skilled population and sustaining economic development. At the same time, governing sciences have been transformed to consider (and also to justify) new modes of training and skills expected from the labour market but also changes in welfare programs more open to business, social innovation and entrepreneurship.

Of course, the economic rationale is not alone in legitimising this new trend. As it can be observed in the past, reformist arguments are also mobilised to advocate changes for social justice and the reduction of inequalities. Today, there are many voices to defend social inclusion, gender equality, second-chance programs, soft skills, etc. The transformation of welfare is also based on reformist proposals and projects carried by organisations and activists committed to making the life of people better and reducing social inequalities. However, in the process of rationalising welfare state interventions and adapting them to the labour market, as well as to cost-efficiency measurements related to budgetary constraints, metrics also serve politics by other means.

By adopting a history of the present, this article has sought to take a reflexive and critical distance from reformist discourses that take data provided by large surveys and other big data as evidence. This genealogical approach shows that issues of governing school populations, but also of selecting, reproducing, and recognising individual capacities, reveal certain social and political conventions on inequalities. These conventions are never stabilised: They evolve with the progress of quantification techniques, but also with changing values, beliefs, and interests, about what is fair and good for educating the young generation. This is also a matter of constructing equivalence between metrics and norms, 
which corresponds to equivalent words in Latin: norma, the square that measures and the rule that prescribes.

\section{Acknowledgments}

I am very grateful to Kenneth Horvath and Regula Leeman for their relevant and supporting advice during the writing of this article. With my eternal gratitude to Tom Popkewitz and my mentor, Laurent Thévenot.

\section{Conflict of Interests}

The author declares no conflict of interest.

\section{References}

Alexiadou, N., Fink-Hafner, D., \& Lange, B. (2010). Education policy convergence through the open method of coordination: Theoretical reflections and implementation in 'old' and 'new' national contexts. European Educational Research Journal, 9(3), 345-358.

Bannister, R. C. (1987). Sociology and scientism: The American quest for objectivity, 1880-1940. University of North Carolina Press.

Bauer, R. A. (1966). Social indicators. MIT Press.

Bulmer, M. (Ed.). (1978). Social policy research. Macmillan.

Bulmer, M. (1983). The methodology of early social indicator research: William Fielding Ogburn and 'recent social trends,' 1933. Social Indicators Research, 13(2), 109-130.

Bulmer, M. (1984). The Chicago school of sociology: Institutionalization, diversity, and the rise of sociological research. University of Chicago Press.

Bulmer, M. (1985). The development of sociology and empirical social research in Britain. In M. Bulmer (Ed.), Essays on the history of British sociological research (pp. 3-36). Cambridge University Press.

Callahan, R. E. (1962). Education and the cult of efficiency. University of Chicago Press.

Callon, M. (2010). Performativity, misfires and politics. Journal of Cultural Economy, 3(2), 163-169.

Callon, M., \& Muniesa, F. (2005). Peripheral vision: Economic markets as calculative collective devices. Organization Studies, 26(8), 1229-1250.

Camic, C., \& Yue, X. (1994). The statistical turn in American social science: Columbia University, 1890 to 1915. American Sociological Review, 59, 773-805.

Campbell, D. T. (1969). Reforms as experiments. American Psychologist, 24, 409-429.

Campbell, D. T. (1975). The social scientist as methodological servant of the experimenting society. In S. S. Nagel (Ed.), Policy studies and the social sciences (pp. 27-32). Transaction Publishers.

Campbell, D. T., \& Stanley, J. (1963). Experimental and quasi-experimental designs for research. Rand McNally.

Chiapello, E., \& Walter, C. (2016). The three ages of finan- cial quantification: A conventionalist approach to the financiers' metrology. Historical Social Research, 41(2), 155-177.

Cobb, C. W., \& Rixford., C. (1998). Lessons learned from the history of social indicators. Redefining Progress.

Coleman, J. S., Campbell, E. Q., Hobson, C. J., McPartland, F., Mood, A. M., Weinfeld, G. D., \& York. R. L. (1966). Equality of educational opportunity. U.S. Government Printing Office.

Danziger, K. (1994). Constructing the subject: Historical origins of psychological research. Cambridge University Press.

Dehue, T. (2001). Establishing the experimenting society: The historical origin of social experimentation according to the randomized controlled design. History of the Human Sciences, 18(2), 63-86.

Desrosières, A. (1998). The politics of large numbers: A history of statistical reasoning. Harvard University Press.

Desrosières, A. (2002). Three studies on the history of sampling surveys: Norway, Russia-USSR, United States. Science in Context, 15(3), 377-383.

Desrosières, A. (2011). The economics of convention and statistics: The paradox of origins. Historical Social Research, 36(4), 64-81.

Diaz-Bone, R., \& Didier, E. (2016). Introduction: The sociology of quantification-perspectives on an emerging field in the social sciences. Historical Social Research, 41(2), 7-26.

Dolowitz, D., Hadjiisky, M., \& Normand, R. (Eds.). (2020). Shaping policy agendas: The micro-politics of economic international organizations. Edward Elgar Publishing.

Espeland, W. N., \& Sauder, M. (2016). Engines of anxiety: Academic rankings, reputation, and accountability. SAGE.

Espeland, W. N., \& Stevens, M. L. (2008). A sociology of quantification. European Journal of Sociology, 49(3), 401-436.

Esping-Andersen, G., Gallie, D., Hemerijck, A., \& Myles, J. (2001). A new welfare architecture for Europe. European Centre for Social Welfare Policy and Research.

Esping-Andersen, G., Gallie, D., Hemerijck, A., \& Myles, J. (2002). Why we need a new welfare state. Oxford University Press.

European Commission. (2010). A strategy for smart, sustainable and inclusive growth.

European Commission. (2013a). Investing in social Europe. Publications Office of the European Union.

European Commission. (2013b). Towards social investment for growth and cohesion-Including implementing the European social fund.

European Commission. (2013c). Evidence on demographic and social trends. Social policies' contribution to inclusion.

European Commission. (2015). Policy roadmap for the implementation of the social investment package and the economy. 
European Commission. (2018). Monitoring the implementation of the European Pillar of Social Rights.

Fenwick, T., \& Edwards, R. (2010). Actor-network theory in education. Routledge.

Fenwick, T., \& Landri, P. (2012). Materialities, textures and pedagogies: Socio-material assemblages in education. Pedagogy, Culture \& Society, 20(1), 1-7.

Foucault, M. (2002). The archaeology of knowledge. Routledge.

Gigerenzer, G., Swijtink, Z., Porter, T., Daston, L., \& Kruger, L. (1990). The empire of chance: How probability changed science and everyday life (No. 12). Cambridge University Press.

Glass, D. L. (Ed.). (1954). Social mobility in Britain. Routledge \& Kegan Paul.

Gorur, R. (2011). ANT on the PISA trail: Following the statistical pursuit of certainty. Educational Philosophy and Theory, 43(1), 76-93.

Gorur, R. (2014). Towards a sociology of measurement in education policy. European Educational Research Journal, 13(1), 58-72.

Greenberg, D., \& Robins, P. (1986). Social experiments in policy analysis. Journal of Policy Analysis and Management, 5(2), 340-36.

Hacking, I. (1990). The taming of chance. Cambridge University Press.

Halsey, A. H., Floud, J. E., \& Anderson, C. A. (Eds). (1961). Education, economy and society. The Free Press of Glencoe.

Halsey, A. H., Floud, J. E., \& Martin, F. M. (1956). Social class and educational opportunity. William Heinemann.

Hanushek, E. A., \& Woessmann, L. (2011). How much do educational outcomes matter in OECD countries? Economic Policy, 26(67), 427-491.

Haverman, R. H. (1987). Poverty policy and poverty research. University of Wisconsin Press.

Hemerijck, A. (2013). Changing welfare states. Oxford University Press.

Hemerijck, A. (2018). Social investment as a policy paradigm. Journal of European Public Policy, 25(6), 810-827.

Henry, M., Lingard, B., Rizvi, F., \& Taylor, S. (2001). The $O E C D$, globalisation and education policy. Pergamon.

Hogben, L. (Ed.). (1938). Political arithmetic. A symposium of population studies. Macmillan.

Hutt, E. L. (2016). Surveying the nation: Longitudinal surveys and the construction of national solutions to educational inequity. Ethics and Education, 11(2), 240-258.

Hutt, E. L. (2017). Seeing like a state in the postwar era: The Coleman report, longitudinal datasets, and the measurement of human capital. History of Education Quarterly, 57(4), 615-625.

Jones, L. V. (1996). A history of the national assessment of educational progress and some questions about its future. Educational Researcher, 25(7), 15-22.

Kent, R. (1985). The emergence of the sociological sur- vey 1887-1939. In M. Bulmer (Ed.), Essays on the history of British sociological research (pp. 52-69). Cambridge University Press.

Lampland, M. (2010). False numbers as formalizing practices. Social Studies of Science, 40(3), 377-404.

Latour, B. (2005). Reassembling the social: An introduction to actor-network-theory. Oxford University Press.

Lemann, N. (2000). The big test: The secret history of the American meritocracy. Macmillan.

Lehmann, I. J. (2004). The Genesis of NAEP. In L. V. Jones \& O. Olkin (Eds.), The nation's report card. Evolution and perspectives (pp. 25-92). Phi Delta Kappa Educational Foundation.

Lindblad, S., Daniel Pettersson, D., \& Popkewitz, T. S. (Eds.). (2018). Education by the numbers and the making of society. The expertise of international assessments. Routledge.

Lupton, D. (2016). The quantified self. Polity Press.

Maire, S. (2020). The power of 'soft skills': The role of the OECD in the shaping of a new cognitive motive in the global agora of education. In D. Dolowitz, M. Hadjiisky, \& R. Normand (Eds), Shaping policy agendas the micro-politics of economic international organizations. Edward Elgar Publishing.

McCall, W. A. (1923). How to experiment in education. Palgrave Macmillan.

McCloskey, D. (2002) The secret sins of economics. University of Chicago Press.

Miller, P., \& Rose, N. (2008). Governing the present: Administering social and personal life. Polity Press.

Morel, N., Palier, B., \& Palme, J. (Eds.). (2012). Towards a social investment state? Ideas, policies and challenges. Policy Press.

Mosteller, F., \& Boruch, R. (Eds.). (2002). Evidence matters. Randomized trials in education research. Brookings Institution Press.

Muniesa, F. (2014). The provoked economy: Economic reality and the performative turn. Routledge.

Neff, G., \& Nafus, D. (2016). Self-tracking. MIT Press.

Normand, R. (2010). Expertise, networks and indicators: The construction of the European strategy in education. European Educational Research Journal, 9(3), 407-421.

Normand, R. (2013). Governing population: The emergence of a political arithmetic of inequalities in education. A comparison between the United Kingdom and France. In M. Lawn (Ed.), The rise of data, historical perspectives (pp. 139-157). Symposium Books.

Normand, R. (2016). The changing epistemic governance of European education: The fabrication of the Homo Academicus Europeanus? (Vol. 3). Springer.

Normand, R. (2020). The politics of metrics in education: A contribution to the history of the present. In G. Fan \& T. Popkewitz (Eds.), Handbook of education policy studies (pp. 345-362). Springer.

Normand, R., \& Pacheco, R. (2014). Constructing the lifelong learning self: European politics and the sense of 
justice. In M. Milana \& J. Holford (Eds.), Adult education policy and the European Union: Theoretical and methodological perspectives (pp. 91-107). Brill Sense.

Nicholls, A., \& Murdock, A. (Eds.). (2011). Social innovation: Blurring boundaries to reconfigure markets. Springer.

O’Neil, C. (2016). Weapons of math destruction: How big data increases inequality and threatens democracy. Crown Publishers.

Platt, J. (1996). A history of sociological research methods in America, 1920-1960. Cambridge University Press.

Popkewitz, T. (2013). The sociology of education as the history of the present: Fabrication, difference, and abjection. Discourse: Studies in the Cultural Politics of Education, 34(3), 439-456.

Popkewitz, T. S. (2018). Reform and making human kinds: The double gestures of inclusion and exclusion in the practice of schooling. In E. Hultqvist, S. Lindblad, \& T. S. Popkewitz (Eds.), Critical analyses of educational reforms in an era of transnational governance ( $\mathrm{pp}$. 133-150). Springer.

Popkewitz, T., \& Lindblad, S. (2020). Statistics reasoning and its "acting" in educational policy. In G. Fan \& T. Popkewitz (Eds.), Handbook of education policy studies (pp. 381-398). Springer.

Porter, T. M. (1995). Trust in numbers. The pursuit of objectivity in science and public life. Princeton University Press.

Power, M. (1997). The audit society: Rituals of verification. Oxford University Press.

Schneider, W. H. (2002). Quality and quantity: The quest for biological regeneration in twentieth-century France. Cambridge University Press.

Scot, M. (2011). La London School of Economics and Political Science 1895-2010. Internationalisation universitaire et circulation des savoirs [The London School of Economics and Political Science 1895-2010. Academic internationalisation and circulation of knowledge]. PUF.

Soloway, R. A. (1990). Demography and degeneration:
Eugenics and the declining birth rate in twentiethcentury Britain. University of North Carolina Press.

Sutherland, G., \& Sharp, S. (1984). Ability, merit, and measurement: Mental testing and English education, 1880-1940. Oxford University Press.

Thévenot, L. (1984). Rules and implements: Investment in forms. Social Science Information, 23(1), 1-45.

Thévenot, L. (2011). Conventions for measuring and questioning policies. The case of 50 years of policy evaluations through a statistical survey. Historical Social Research, 36(4), 192-217.

Thévenot, L. (2016). From social coding to economics of convention: A thirty-year perspective on the analysis of qualification and quantification investments. Historical Social Research, 41(2), 96-117.

Thévenot, L. (2019). Measure for measure. Historical Social Research, 44(2), 44-76.

Tuijnman, A. (2003). Measuring lifelong learning for the new economy. Compare: A Journal of Comparative and International Education, 33(4), 471-482.

Turner, S. P., \& Turner, J. H. (1990). The impossible science: An institutional analysis of American sociology. SAGE.

Tyack, D. (1974). The one best system: A history of American urban education. Harvard University Press.

Tyack, D., \& Hansot, H. (1982). Managers of virtue: Public school leadership in America. 1820-1980. Basic Books.

Tyler, R. W. (1966). The objectives and plans for a national assessment of educational progress. Journal of Educational Measurement, 3(1), 1-4.

Whitehead, F. (1985). The government social survey. In M. Bulmer (Ed.), Essays on the history of British sociological research (pp. 83-100). Cambridge University Press.

Wooldridge, A. (1994). Measuring the mind. Education and psychology in England. 1860-1990. Cambridge University Press.

Young, K., Ashby, D., Boaz, A., \& Grayson, L. (2002). Social science and the evidence-based policy movement. Social Policy and Society, 1, 215-224.

\section{About the Author}

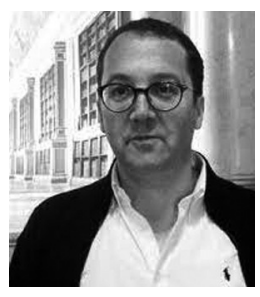

Romuald Normand is leading the French Chinese Chair on education policies in Europe at the University of Strasbourg. His main research topics are comparative education and policy studies. He has developed research projects on metrics and accountability systems in education, lifelong learning and European policy/politics, higher education and the new academic work, new public management and professions, evidence-based education, and expertise. He is head of the Chinese French Centre for Innovation in Education and associate professor at Beijing Normal University, China, as well as honorary professor at the Aarhus-Copenhagen University, Denmark. 